\title{
INTERPRETASI HADIST TENTANG PERANAN WANITA DALAM DINAMIKA SOSIAL
}

\author{
Ms. Udin \\ Fakultas Dakwah Dan Ilmu Komunikasi \\ Universitas Islam Negeri Mataram
}

\begin{abstract}
Abstrack
Today, Indonesia is experiencing a crisis in a number of fields. In addition to experiencing the economic crisis, Indonesia is also being hit by a moral, mental and spiritual crisis. Most of the objects which at the same time cause the crisis are women. Starting from pornography cases, showing off bodies, erotic dances, and many more being the main target and the bait is women. Women can be used as resources to improve society. Women can also be a means to destroy and destroy society. Throughout history, women have struggled to get their rights. However, now they are back in colonialism, namely in the form of modern occupation. Women consider themselves independent when they can show off their beautiful bodies to be enjoyed by masculine men. Women now have forgotten the nature of themselves, they tend to accentuate their facial beauty and beauty without noticing the beauty of their character.
\end{abstract}

Key Word : Interpretasi, Hadist, Peranan Wanita 


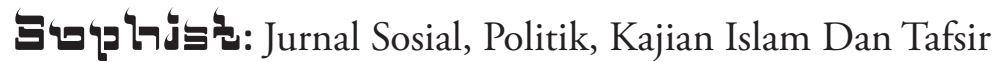

\section{A. Pendahaluan}

Dewasa ini, Indonesia sedang mengalami krisis di sejumlah bidang. Selain mengalami krisis ekonomi, Indonesia juga sedang dilanda krisis moral, mental, dan spiritual. Dalam sepanjang sejarah, perempuan telah berjuang untuk mendapatkan hak-haknya. Namun, sekarang mereka kembali terjerumus dalam penjajahan yaitu berupa penjajahan modern. Perempuan menganggap dirinya merdeka di saat dapat memamerkan tubuh moleknya untuk dinikmati laki-laki hidung belang. Perempuan sekarang telah lupa akan hakikat dirinya, mereka cenderung menonjolkan kecantikan wajah dan kemolekan tubuhnya tanpa memerhatikan kecantikan budi pekertinya.

Salah satu kendala bagi perempuan Indonesia adalah adanya kontradiksi antara karir dan keluarga. Seolah-olah perempuan dipaksa memilih karir atau keluarga. Jika memilih karir, pada tahun-tahun pertama usianya, seorang anak sangat membutuhkan perhatian, kasih sayang, dan belaian dari seorang ibu. Dalam psikologi dijelaskan, tahuntahun pertama kehidupan anak adalah masa-masa ketergantungan yang sangat besar dari seorang anak kepada ibunya. Jika kebutuhan anak tidak terpenuhi, anak akan cenderung mengalami krisis kepercayaan diri. Sementara itu, jika perempuan mengambil pilihan kedua, yaitu memilih keluarga dan meninggalkan karirnya, dia akan merasa bahwa segala jerih payahnya selama ini, misalnya menuntut ilmu telah tersiasiakan.

Dengan kata lain, perempuan karir di Indonesia pada umumnya menghadapi dilema besar, yang hanya bisa terpecahkan bila pemerintah turun tangan untuk memberikan fasilitas yang member kesempatan kepada perempuan agar tetap bisa berkarir sekaligus melaksanakan tugas sebagai seorang ibu.

Dengan memperhatikan peristiwa-peristiwa yang terjadi di tanah air, maka tidak benar jika perempuan hendak diposisikan sebagai manusia kelas dua. Hal yang harus dilakukan adalah bagaimana memposisikan perempuan secara adil dan setara dalam 
politik, karena pada kenyataannya banyak laki-laki yang tidak lebih baik dari perempuan, tetapi sebagian besar perempuan dipandang sebagai pihak yang lemah ketika masuk ranah politik. Pandangan ini tentu tidak adil terhadap perempuan, karena harus disingkirkan.

Dalam kondisi ini, perempuan yang sadar memiliki tugas untuk mencerahkan dan mengingatkan saudara-saudaranya akan peran dan tugas yang harus dipikul perempuan, baik melalui pendekatan maupun pelatihan. Tugas ini akan berhasil jika dilakukan oleh sesama perempuan, karena persamaan perempuan yang memiliki kekuatan emosional, akal, dan karena perempuan yang mengetahui bagaimana perasaan yang dirasakan oleh sesamanya.

Umumnya, perempuan cenderung peka terhadap lingkungan sekitarnya. Gerakan perempuan perlu mempertahankan keterbukaan pikiran, siap mendengarkan, berdialog serta bernegoisasi dengan berbagai kelompok yang ada dalam masyarakat.

Posisi dan kedudukan perempuan dalam bermasyarakat dan bernegara yakni sebagai anggota masyarakat dan sebagai warga negara yang memiliki sejumlah hak dan kewajiban (right and obligation), seperti firman Allah dalam Qur'an surah An-Nisa' ayat 29-33, yang menjelaskan bahwa Islam melindungi hak milik laki-laki dan perempuan. Tidak ada perbedaan antara laki-laki dan perempuan. Perintah Allah untuk berbuat adil dalam seluruh bidang kehidupan, baik ranah domestic maupun public sangat tegas, keadilan harus ditegakkan. Keadilan merupakan prinsip ajaran Islam yang harus ditegakkan dalam menata kehidupan manusia, prinsip harus selalu ada dalam setiap norma, tata nilai, dan perilaku umat manusia di manapun dan sampai kapanpun

Isu kesenjangan gender merupakan isu yang sangat kompleks dan tidak pernah selesai dianggap sebagai masalah. Hingga saat ini perbedaan kedudukan perempuan dan laki-laki masih dapat ditemukan, tidak terkecuali dalam pemerintahan, dan juga di lembagalembaga swasta. Terlebih dalam hal kepemimpinan, perempuan masih 
berada dibawah jumlah laki-laki yang berperan sebagai pemimpin. Hal ini terbukti dengan Indeks Kesenjangan Gender (IKG) yang diliput media cetak Kompas tanggal 31 agustus 2018 menunjukan bahwa Indonesia berada pada peringkat 105 dari 188 negara di dunia. Peringkat tersebut salah satunya dinilai dari jumlah perempuan di kursi di parlemen, dan partisipasi angkatan kerja secara formal maupun informal masih sangat sedikit.Fakta lain menunjukan bahwa jumlah perempuan sebagai pemimpin dalam birokrasi masih sangat rendah. Budaya patriarkhi masih kental dalam masyarakat indonesia. Perempuan hanya diperbolehkan memainkan peran domestik seperti urusan dalam internal rumah tangga. Kondisi seperti diatas ternyata tidak hanya ditemukan di daerah pedesaan, namun juga terjadi di daerah perkotaan. Ditingkat kelurahan yang merupakan level terendah pemerintahan di daerah perkotaan seperti di DKI, jumlah perempuan juga sedikit. Data menunjukan bahwa jumlah Lurah perempuan di Provinsi DKI dari seluruh jumlah Lurah 267 menunjukan angka $20 \%$, yang artinya bahwa masih rendah dibandingkan dengan jumlah Lurah laki-laki yang berjumlah $80 \%$. Pembedaan fungsi dan peran antara laki-laki dan perempuan tidak ditentukan karena keduanya terdapat perbedaan biologis atau kodrat, melainkan dibedakan menurut kedudukan, fungsi, dan peranan masing-masing dalam kehidupan sosial budaya. Perbedaan itu disebut gender, yang dapat diartikan secara umum sebagai perbedaan yang tampak antara lakilaki dan perempuan apabila dilihat dari nilai tingkah laku. Aspek yang membedakan perempuan dan laki-laki tersebut seringkali menjadi patokan masyarakat dalam menentukan pemimpinnya. ${ }^{1}$

Islam mengatur sistem dan pola kehidupan yang menyeluruh dari semua aspek yang menyentuh seluruh sendi-sendi kehidupan. Berbicara konteks politik, Islam juga mengatur peran dan posisi wanita dalam kaitannya dengan kepemimpinan Islam dan perannya dalam kancah perpolitikan.

1http://data.jakarta.go.id/dataset/data-lurah-di-lingkungan-pemerintah-provinsi-dkijakarta,,,,,, diakses pada tanggal 07 November 2017 Pukul 14.50 WIB 
Dalam ajaran Islam, ucapan kepribadian dan perbuatan nabi Muhammad SAW merupakan pegangan dan uswah (suri tauladan) bagi kaum muslimin. Selain itu sejarah perjuangannyapun dijadikan motifasi bagi umat islam dalam melanjutkan dakwah menyebarkan amar makruf dan nahi mungkar. Oleh karena itu siapa saja yang ingin mengetahui metodologi keberhasilan perjuangan, karekateristik dan pokok-pokok ajaran nabi Muhamnmad SAW maka hal tersebut dapat dipelajari secara rinci dalam sunnah nabawiyah

Hadist nabi Muhammad SAW selain sebagai sumber ajaran Islam yang kedua setelah al-Qur'an juga berfungsi sebagai sumber sejarah dakawah dan perjuangan rasululloh SAW, hadist juga mempunyai fungsi sebagai penjelas bagi al-Qur'an, menjelaskan yang global, menghususwkan yang umum dan memberikan interprestasi terhadap ayat-ayat al-Qur'an

Dalam interpretasi dengan corak tekstual ini, seorang penafsir dalam mengintrepretasikan Hadîts Nabi saw membatasi pandangannya hanya terhadap teksnya saja, yaitu tidak mempertimbangkan konteks historis Hadîts dan kaitannya dengan hal-hal kekinian yang sedang dihadapi umat Islam di mana dan kapan mereka berada. Para ulama’ tekstualis pada umumnya dari kalangan ahli Hadîts yang produk fiqihnya diistilahkan dengan fiqh tradisional dan dipelopori oleh Imam Mâlik Bin Anas.

Penafsiran terhadap Hadîts dengan melihat konteks-historis yang kongkrit yakni dalam penafsiran Hadîts itu didasarkan atas analogi historis-kontekstual antara dunia Nabi Muhammad yang Arabik pada masa lima belas abad yang lalu dengan dunia umat Islam lain yang hidup di zaman serta wilayah yang berbeda, sehingga dapat mengimplimentasikan kandungan Hadîts Nabi dalam konteks perkembangan kehidupan yang terus berjalan. Pandangan kontekstualisme selalu bersebrangan dan bahkan menolak terhadap setiap interpretasi tekstual yang memilah dan memutuskan antara fakta dimana dan kapan Nabi Muhamad saw hidup dengan realitas 


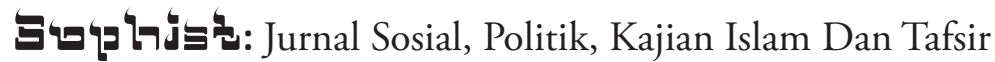

umat Islam sekarang.

\section{B. Pembahasan}

\section{Interpretasi Tentang Peranan Wanita Dalam Islam}

Adanya dua bentuk interpretasi atau lebih terhadap Hadîts tersebut menimbulkan konsekuensi dan ekses besar dalam pemikiran Islam, utamanya dalam produk hukum fiqih, misalnya perbedaan produk hukum fiqih madzhab Syâfi'î dengan produk madzhab Mâlikî, hal itu karena terdapat perbedaan manhaj dalam menginterpretasikan teks-teks agama (al Qur'an dan al-Sunnah). Imam Syâfi'î secara umum adalah kontekstualis sedangkan Imam Mâlik cendrung tekstualis. ${ }^{2}$

Terjadinya perbedaan pandangan antara para pakar dan pemikir muslim klasik itu menimbulkan implikasi besar terhadap corak pola pikir para tokoh masyarakat di Indonesia dalam menyikapi beberapa permasalahan kontemporer yang menimpa bangsa ini, di antaranya adalah :

a. Wanita Sebagai Pemimpin

Dalam pandangan Islam, kepemimpinan merupakan amanah dan tanggung jawab yang tidak hanya dipertanggung jawabkan kepada anggota-anggota yang dipimpinnya, tetapi juga akan dipertanggung jawabkan dihadapan Allah SWT Berkaitan dengan kepemimpinan, tidak ada batasan antara laki-laki dan perempuan, keduanya samasama memiliki hak untuk menjadi pemimpin. Perempuan dituntut untuk terus belajar dan meningkatkan kualitas diri sehingga dapat mempengaruhi orang lain dengan argumentasi-argumentasi ilmiah dan logis. Kalau hal tersebut dapat diraih perempuan, maka perempuan memiliki dua "senjata" yang sangat ampuh, yakni pertama perasaan halus yang dapat menyentuh kalbu, dan kedua argument kuat yang menyentuh nalar. Kemampuan menyentuh rasa tanpa sentuhan nalar tidak cukup untuk mewujudkan kepemimpinan yang sehat Seorang pemimpin ideal harus memiliki kriteria kemampuan

2 Harun Nasution, Islam Rasional, (Bandung: Mizan, 1995), hlm. 78.

174 Interpretasi Hadist Tentang Peranan Wanita.... 
memimpin, dapat dipercaya dan mempercayai orang lain, mencintai kebenaran dan mampu menegakkan hukum. Setidaknya ada dua pendapat mengenai kepemimpinan wanitadalam Islam. Pendapat pertama mangatakan bahwa wanita dalam. Islam tidak bisa menjadi pemimpin dalam kehidupan publik, Sementara pendapat kedua menyatakan sebaliknya bahwa sejalan dengan konsep kemitrasejajaran yang diajarkan Islam maka wanita boleh menjadi pemimpin dalam masyarakat atau dalam kehidupan publik

Berkenaan dengan masalah jender ini baginda Rasul saw telah bersabda dalam sebuah Hadîtsnya yang diriwayatkan oleh imam Bukhari ${ }^{3}$ :

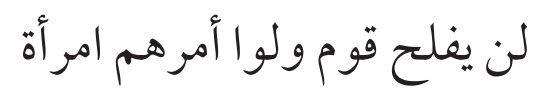

Artinya: "Tidak akan beruntung suatu kaum jika menyerahkan urusannya kepada perempuan".

Dalam menyikapi hal tersebut muncul dua paradigma yang sangat berbeda antara kelompok yang melihat Hadîts ini secara tekstual dengan kelompok lain yang memandang dari segi konteksnya ${ }^{4}$. Di mana kelompok pertama yang tekstualis menyatakan bahwa sosok wanita sama sekali tidak boleh menempati posisi puncak kepemimpinan dalam pemerintahan pada sebuah negara, sebagaimana yang terjadi di Indonesia misalnya, dimana perempuan menempati kedudukan sebagai Presiden. Maka menurut pandangan kelompok yang pertama yang tekstualis bahwa hal tersebut tidak boleh dan dianggap menyalahi agama, karena kedudukan presiden sebagai posisi nomor satu dalam sebuah negara, dan memang secara tekstual Hadîts tersebut menolak hal itu.

Dan dengan berlandaskan Hadîts Nabi di atas pula sebagian

3 Al-Bukhâri, Shahîh al-Bukhârî, Juz 2 (Kairo: Mathba'ah Salafîyah, 1990), hlm. 326.

4 Quraisy Syihab, Membumikan al-Qur 'an (Bandung: Mizan, 1998), hlm. 314, 
ulama memutuskan bahwa perempuan tidak boleh menduduki jabatan sebagai penegak hukum (al-hakim) kecuali dalam kondisi mendesak dan terpaksa (li al-dharûrah), dan jabatan kepala desa termasuk dalam kategori al-hakim juga ${ }^{5}$. Maka dengan berdasarkan al-qiyâs al-awlâwî lebih tidak boleh bagi sosok wanita untuk menempati jabatan yang lebih tinggi seperti bupati, gubernur dan apalagi jabatan presiden.

Sedangkan kelompok yang kedua yang kontekstualis tidak mempermasalahkan kepemimpinan wanita secara mutlak, baik pada kepemimpinan puncak ataupun kepemimpinan pada level di bawahnya. Kelompok ini memandang Hadîts tersebut dari segi konteksnya, di mana baginda Rasulullah dalam Hadîts ini menyoroti bangsa Persia yang dianggap kurang tepat dalam mengatur sistem pemerintahannya, karena mereka telah menempatkan sosok wanita pada posisi kepemimpinan puncak dalam pemerintahan, padahal kaum wanita di kalangan mereka pada saat itu sangat tertinggal dan terbelakang utamanya dalam dunia politik dan pendidikan, dan oleh karena itu dianggap tidak layak untuk menduduki posisi puncak dalam pemerintahan. Itulah sebabnya sehingga mendapat sorotan dari baginda Rasulullah. Maka menurut kelompok yang kedua Hadîts ini merupakan suatu koreksi terhadap bangsa Persia yang telah keliru dalam memposisikan sosok wanita, dan bukan pelarangan terhadap kepemimpinan puncak bagi wanita dalam suatu negara.

Bertolak dari itu menurut kelompok yang kedua ini, tidak ada masalah bagi sosok wanita yang sudah memenuhi kreteria dan sudah mempunyai kelayakan, untuk menjabat sebagai seorang presiden dimana saja dan kapan saja. Di samping itu pula dalam konteks Indonesia bahwa presiden di negeri ini sebenarnya bukanlah pemimpin puncak, karena di atasnya masih ada kepemimpinan yang lebih tinggi sebagai pejabat tertinggi negara yaitu MPR ${ }^{6}$.

5 Sebenarnya ini adalah masalah kontrofersi antara jumbur ( Madzhab Hanafi, Mâlikî, Syâfi'î, Hanbalî) dengan Ibnu Jarir al-Thobari

6 ernyatan KH. Hasyim Muzadi dalam sebuah acara Temu Kandidat CapresCawapres pada stasiun Lativi tanggal 20 Juni 2004

176 Interpretasi Hadist Tentang Peranan Wanita.... 
b. Pembagian Harta

Dalam pembagian harta warisan di Indonesia sudah berlaku satu sistem pembagian harta warisan (tirkat) yang disebut sistem gana-gini yang dianggap sebagai pengembangan dari sistem farâidh yang digariskan dengan berdasarkan nash (al-Qur'ân dan al-Hadîts). Pola pembagian harta warisan dengan sistem gana-gini ini sudah diterapkan dan bahkan sudah menjadi tradisi pada sebagian kawasan di Indonesia. Dan penerapan sistem ini merupakan satu bentuk ijtihâd dari sebagian tokoh masyarakat (kyai) di Indonesia yang terpaksa dilakukan karena munculnya rasa ketidak puasan dari sebagian masyarakat awam terhadap sistem farâidh yang ada.

Fenomena ini termasuk bagian dari penerapan sistem yang sudah mengarah kepada pandangan yang kontekstual, yakni penerapan terhadap teks keagamaan dengan mempertimbangkan sosio kultural masyarakat yang ada, di mana suami dan isteri sama-sama bekerja, misalnya sama-sama pegawai negeri, pedagang, atau petani, bahkan kadang-kadang yang bekerja lebih berat justru sang isteri, berbeda sama sekali dengan sosio kultural masyarakat Arab pada masa lima belas abad silam di mana peran sang isteri pada masa itu pada umumnya hanya sebatas sebagai ibu rumah tangga saja.

Penulis melihat bahwa tanpa menggunakan sistem gana-gini, sepertinya sulit sekali sistem farâidh untuk bisa diterima oleh masyarakat (masyarakat awam tentunya) pada kawasan tertentu di Indonesia.

Sebagian ulama membolehkan pembagian harta warisan dengan menggunakan sistem gana-gini tersebut, namun dengan syarat mendapat persetujuan dari para ahli waris ${ }^{77}$. Artinya jika ada salah satu dari ahli waris yang mengadukan penerapan sistem ini, maka harus kembali kepada aturan pembagian harta warits sebagaimana yang diatur oleh ilmu farâidh.

Sementara kelompok yang berpandangan tekstual menolak

7 Lajnah Ta'lif, Abkamul Fuqaha', hlm , 38 


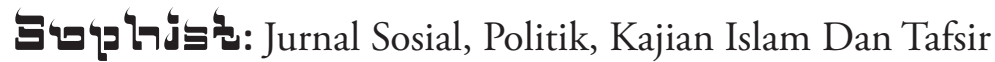

terhadap penerapan gana-gini tersebut sebab dianggap menyalahi aturan yang digariskan oleh nash. Dalam artian tidak membuka peluang untuk ijtihâd dan pengembangan, seperti apapun bentuknya dan apapun alasannya, karena anggapan mereka bahwa aturan pembagian harta warisan itu sudah baku dan sudah paten berlaku untuk umat Islam dimanapun mereka berada dan kapan pun mereka hidup.

Kaitannya dengan masalah ini, cukup menarik paparan yang ditulis oleh Sjechul Hadi Permono, di mana beliau berpandangan bahwa teks-teks agama dapat dikategorikan kepada dua bentuk. Pertama, teks agama yang sifatnya dogmatis, yang tidak mungkin untuk diinterpretasikan secara kontekstual, sehingga hukum Islam yang diistimbathkan dari teks-teks semacam itu bersifat dogmatis pula yang tidak ada jalan bagi para fuqaha' untuk manambah ataupun menguranginya, dan dalam kategori yang pertama ini pintu ijtihâd tertutup. Kedua, ada pula teks agama yang terbuka untuk diinterpretasikan secara kontekstual, dan produk hukum Islam yang diistinbathkannya pun masih membuka peluang terhadap upayaupaya ijtihâd.

Dan untuk lebih jelasnya penulis akan memaparkan dua hal tersebut sebagai berikut:

a. Bagian-Bagian Hukum Islam

Hukum Islam yang dibawa oleh Nabi kita sangat luas ruang lingkupnya karena mencakup berbagai sisi kehidupan orang mukallaf, dan hukum Islam tersebut dapat dikategorikan kepada beberapa bidang :

1. Hukum Islam yang mencakup hal-hal ibadah seperti shalat, puasa, haji dan lain sebagainya yang bersifat dogmatis (unreasonable) merupakan bidang dimana kita tidak boleh menambah, merubah, mengurangi apa yang telah ada, dan tidak ada ruang ijtihâd di dalamnya. Bidang yang pertama

178 Interpretasi Hadist Tentang Peranan Wanita.... 
ini diistilahkan dengan "syarîah".

2. Hukum Islamyangmencakuphal-hal sosial kemasyarakatan dan transaksi dan lain sebagainya yang diistilahkan dengan fiqh mu'âmalah. Hukum Islam bidang kedua ini dibagi dua lagi yaitu :

a) Bidang mu'âmalah khâss yang merupakan ketentuanketentuan yang bersandar pada nash-nash agama dari al-Qur'ân Hadîts yang qath'î (terinci, tegas dan pasti). Hukum mu'âmalah bidang ini termasuk kategori syarîah sama dengan bidang pertama yang sifatnya dogmatis, seperti hukum-hukum pidana yang berbentuk sangsi-sangsi syara' ( $h u d u d$ ) semacam qishâs, potong tangan dan jild (hukum cambuk) yang dalil syar'inya sudah jelas, shârih dan tidak mungkin dita’wil lagi. Dalam hal ini kaum muslim, baik kapasitas kita sebagai umat atau sebagai bangsa, harus menerima ketentuan-ketentuan tersebut menurut apa adanya, tidak perlu ditambah, dikurangi ataupun dirubah karena syara' menganggap bahwa itulah yang paling mashlahah untuk manusia.

b) Bidang mu'âmalah 'âmm (muamalah umum) yang merupakan ketentuan-ketentuan dengan bersumber pada nash-nash agama yang bersifat kullî, semisal hukum-hukum tata negara dan pemerintahan, bentuk-bentuk bertransaksi dalam dunia bisnis dan perekonomian dan lain sebagainya. Ruang ijtihâd dalam bidang ini sangat luas dan nalar akal pikiran sangat lincah tapi penuh tanggung jawab, dan tentunya ijtihâd melalui proses istinbath dengan metode dan sistematika yang shahîh (benar). Dalam

8 Sjechul Hadi Permono, Dinamisasi Hukum Islam dalam Menjawab Tantangan Era Globalisasi (Kudus: Pustaka Firdaus, 1998), hlm:11 
hal ini al-âdah dan al-urf yang tidak bertentangan dengan nash-nash agama dapat dikukuhkan sebagai hukum Islam dalam kategori ini, tentu kita bisa mengembangkan sesuai situasi dan tuntutan kebutuhan zaman. Produk hukum ini disebut "fiqh ".

b. Tajdid Sebuah Upaya Penggalian Hukum Islam

Upaya-upaya tajdîd ini tentunya dilakukan terhadap hukumhukum Islam yang masih bisa memberi peluang terhadap upaya ijtihâd. Hal ini dilakukan dalam rangka untuk memberikan solusi terhadap penyelesaian masalah umat (bangsa), karena tanpa upaya tajdîd dengan selalu mengembangkan ijtihâd tersebut, maka peluang umat Islam untuk ikut serta berkiprah dalam upaya penyelesaian masalah sosial, ekonomi, politik, dan lain-lain akan berkurang, akibat ketidakmampuan menegejar perkembangan zaman yang berjalan cepat.

Kaitannya dengan masalah tajdîd tersebut, mengutip Syarah Ihyầ Ulûm al-Dîn, Sjechul Hadi Permono mendefinisikan, yaitu: ${ }^{10}$

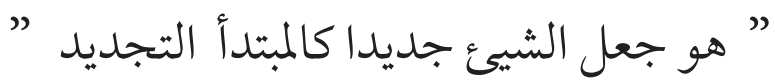

Artinya: Bahwa tajdìd adalah mengembalikan sesuatu menjadi baru sebagaimana mula pertama. Jadi pengertian tajdid di sini mengembalikan sesuatu kepada aslinya (orisinalnya) dan bukan mengganti dengan yang lain yang baru.

Lebih lanjut, ia mengatakan bahwa tajdîd dalam konteks hukum Islam harus memenuhi tiga unsur:

1. Al-ibânah (liberations) dalam arti bahwa dalam melakukan tajdid, kita dalam proses berpikir harus lepas dari fanatisme mazhab.

9 Ibid

10 Sjechul Hadi Permono, Pembaruan Hukum Islam di Indonesia, Makalah disampaikan pada Konferensi Nasional Kajian Islam di Indonesia Tahun 2004 di Banda Aceh, tidak diterbitkan.

180 Interpretasi Hadist Tentang Peranan Wanita.... 
2. Al-iâdah (reformations) artinya kita harus kembali kepada alQur'ân dan al-Hadîts dengan menggunakan metode penggalian hukum yang benar.

3. Al-ihyấ menyesuaikan dengan pergeseran kemaslahatan sebagai refleksi dari kemajuan ilmu pengetahuan modern dan teknologi dan tentunya yang tercakup dalam kemaslahatan-kemaslahatan yang menjadi tujuan syara'.

Berbicara masalah pembaruan hukum Islam, dalam Islam dikenal beberapa bentuk-bentuk hukuman pidana yang diistilahkan dengan ahkâm al-jarâim, yaitu hudud, qishâs, diyat, kaffarah, dan ta'zîr.

Dari bentuk-bentuk hukum pidana Islam tersebut, ada hukuman yang mengandung solidaritas sosial yaitu, diyat dan kaffarat.

Hukum pidana Islam yang mempunyai peluang untuk dikembangkan baik materi maupun cara-cara penegakannya adalah hukuman atas kejahatan yang tidak ditentukan bentuk dan kadar hukumannnya oleh nash al-Qur'ân dan al-Hadîts.

Adapun bentuk-bentuk hukum pidana Islam yang sudah jelas ketentuannya dari syara', hanya dapat diperbarui dari dua sisi :

a. Sisi hukum formalnya, seperti cara-cara pembuktiannya, syarat-syarat formal hukuman bagi orang yang berbuat zina, dan syarat-syarat formal hukuman potong tangan dalam kasus pencurian.

b. Sisi perluasan makna teks sesuai dengan ilmu bahasa dan tujuan syariah seperti; pertama, kontekstualisasi kalimat أربعة (empat saksi) kepada أربع مرات (empat kali tertangkap basah walaupun oleh satu orang). Kedua, perluasan makna سـرقة (pencurian) dengan tidak dibatasi pada pencurian secara sembunyi sebagaimana dalam pegertian klasik.

c. Respon atas Ragam Interpretasi Hadîts

Lepas dari menerima ataupun menolak, penulis memandang 
bahwa adanya dua paradigma dalam pola interpretasi (tekstualis dan kontekstualis) terhadap Hadîts Nabi, di samping mengandung segisegi positif, tentu juga ada sisi negatifnya. Sisi Positifnya; pertama, Bagi kalangan intelektual, dua paradigma tersebut justru menambah khazanah pemikiran Islam yang sangat berharga. Kedua, dualisme interpretasi yang merupakan warisan dari para pemikir terdahulu itu menjadi modal yang cukup segnifikan dalam rangka dinamisasi pola pikir umat. Dimana upaya-upaya yang mengarah kepada rekonsiliasi sering kali kita lihat, yang dikemas dalam bentuk seminar-seminar, bahts al-masâil, simposium, dan sebagainya, sebagai upaya mencari titik temu ${ }^{11}$. Ketiga, Penerapan analogi historis-kontekstual dalam memberikan interpretasi terhadap Hadîts Nabi akan lebih banyak memberikan peluang terhadap Islam untuk dapat memberikan solusi terhadap masalah-masalah kontemporer umat. ${ }^{12}$

Sedangkan sisi negatifnya, penerapan teori kontekstual sangat sulit untuk dipertemukan dengan teori tekstual ${ }^{13}$. Fakta menunjukkan bahwa perbedaan interpretasi terhadap teks-teks agama itu menimbulkan perbedaan pandangan antar umat Islam pada tingkat menengah keatas, namun dalam perkembangannya akhirnya muncul perbedaan dan bahkan perpecahan antar kelompok pada level tengah kebawah. Mungkin masih segar dalam ingatan kita bagaimana pro dan kontra antara para pemikir muslim yang pernah terjadi di Indonesia pada tahun 80-an sehubungan dengan masalah bunga bank, pembagian harta waris, dan lain-lain.

Perpecahan pada level bawah ini sangat rentan terhadap munculnya tindakan-tindakan yang anarkhis, maka dengan demikian kesatuan umat yang selama ini kita dambakan hanyalah menjadi angan-angan belaka, mustahil untuk menjadi kenyataan. ఏangankan perbedaan penafsiran terhadap teks-teks agama tidak akan

$11 \mathrm{Hal}$ semacam itu tidak mungkin akan dilakukan tanpa muncul keragaman interpretasi yang terjadi antara para para ulama' dan para pemikir muslim.

12 Lakspesdam NU, Tashwirul Afkar, Jurnal, edisi 8, hlm, 125

13 Lorens Bagus, Kamus Filsafat (Jakarta: PT. Gramedia Pustaka Utama, 2002), hlm, 489 . 
menimbulkan masalah dalam tubuh umat ini, munculnya multi penafsiran terhadap teks proklamasi, Piagam jakarta dan UUD 45 sudah menimbulkan masalah dalam tubuh bangsa. Dimana setiap orang menklaim dirinya berhak memberikan interpretasi sesuai kehendaknya, maka yang terjadi adalah sangat sulit bagi bangsa ini untuk mencapai apa yang didambakannya.

Sebenarnya jika kita melihat jauh ke belakang, maka akan ditemukan bukti kongkrit yang menunjukkan bahwa pola interpretasi kontekstual terhadap Hadîts Nabi sebenarnya sudah pernah diterapkan oleh sebagian para shahabat justru pada masa Baginda Rasul masih hidup. Dimana mereka dalam sebuah perjalanan bersama baginda Rasul, yaitu dalam peperangan al-Ahzab Beliau bersabda: Jangan ada yang shalat Ashar kecuali di perkampungan Bani Quraizhah". Dalam memahami dan menyikapi Hadîts ini, mereka yang ikut dalam perjalanan tersebut ada yang memahaminya dari segi tekstualnya, dan konsekwensi dari pemahaman tekstual tersebut mereka tidak melakukan sholat Ashar kecuali sesudah sampai di perkampungan Bani Quraizhah, karena teks Hadîts tersebut menunjukkan hal itu.

Sementara yang memahaminya dari segi konteksnya tetap melakukan sholat Ashar di tempat sebelum melakukan perjalanan, dengan pertimbangan bahwa jika mereka sholat di perkampungan Bani Quraizhah dapat dipastikan akan terlambat sebab dipandang waktu tidak cukup melakukan sholat di perkampungan itu, sedangkan mengundur-undur sholat sampai keluar dari waktunya tanpa adanya 'udzur syar'î tidak dibenarkan menurut syari'at Islam. Dan Rasulullah menyikapi kedua pemahaman tersebut dengan bijaksana, bahwa apa yang dilakukan kedua kelompok ini sama-sama benar, satu kelompok memahami secara tekstual dan kelompok lain memahaminya secara kontekstual. ${ }^{14}$

14 Syihab, Membumikan al-Qur'ân, hlm, 125. Terdapat perbedaan lainnya, yaitu perbedaan antara Umar bin Khattab dengan para sahabat yang lain dalam sebuah perjalanan dikala mereka akan melintasi kawasan yang sedang dilanda penyakit menular (thâûn). Mereka berbeda dalam memberikan interpretasi terhadap Hadîts Rasulullah yang mengatakan: " دسلأ| نم كرارف مونجلا نمـف " (Jauhilah orang yang terjangkit penyakit lepra 


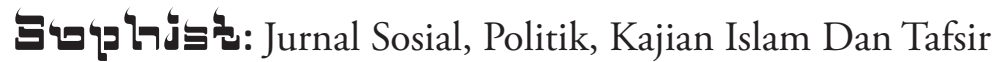

\section{B. Kesimpulan}

Dalam hal kepimipinan wanita terdapat dua paradigma yang sangat berbeda antara kelompok yang melihat Hadîts ini secara tekstual dengan kelompok lain yang memandang dari segi konteksnya. Di mana kelompok pertama yang tekstualis menyatakan bahwa sosok wanita sama sekali tidak boleh menempati posisi puncak kepemimpinan dalam pemerintahan pada sebuah negara, sebagaimana yang terjadi di Indonesia misalnya, dimana perempuan menempati kedudukan sebagai Presiden. Maka menurut pandangan kelompok yang pertama yang tekstualis bahwa hal tersebut tidak boleh dan dianggap menyalahi agama, karena kedudukan presiden sebagai posisi nomor satu dalam sebuah negara, dan memang secara tekstual Hadîts tersebut menolak hal itu.

Dan dengan berlandaskan Hadîts Nabi di atas pula sebagian ulama memutuskan bahwa perempuan tidak boleh menduduki jabatan sebagai penegak hukum (al-hakim) kecuali dalam kondisi mendesak dan terpaksa (li al-dharûrah), dan jabatan kepala desa termasuk dalam kategori al-hakim juga Maka dengan berdasarkan al-qiyâs al-awlâwî lebih tidak boleh bagi sosok wanita untuk menempati jabatan yang lebih tinggi seperti bupati, gubernur dan apalagi jabatan presiden.

Sedangkan kelompok yang kedua yang kontekstualis tidak mempermasalahkan kepemimpinan wanita secara mutlak, baik pada kepemimpinan puncak ataupun kepemimpinan pada level di bawahnya. Kelompok ini memandang Hadîts tersebut dari segi konteksnya, di mana baginda Rasulullah dalam Hadîts ini menyoroti

sebagaimana kamu menjauhi singa) ". Dan para Shahabat yang ikut dalam perjalanan pada saat itu memandang Hadîts ini secara tekstual, sehingga mereka berpanadangan bahwa jika mereka melintasi kawasan tersebut dianggap tidak mematuhi nasehat Rasul, menurut mereka harus mencari jalan lain agar tidak terkena thâûn tersebut. Sedangkan pihak Umar bepandangan kontekstual dengan memandang bahwa Hadîts itu hanyalah sebatas anjuran agar manusia selalu berhati-hati dan waspada, namun kewaspadaan tersebut tidak akan merobah takdir Allah. Maka dalam hal ini beliau lebih memilih tetap melintasi kawasan thầun tersebut.

184 Interpretasi Hadist Tentang Peranan Wanita.... 
bangsa Persia yang dianggap kurang tepat dalam mengatur sistem pemerintahannya, karena mereka telah menempatkan sosok wanita pada posisi kepemimpinan puncak dalam pemerintahan, padahal kaum wanita di kalangan mereka pada saat itu sangat tertinggal dan terbelakang utamanya dalam dunia politik dan pendidikan, dan oleh karena itu dianggap tidak layak untuk menduduki posisi puncak dalam pemerintahan. Itulah sebabnya sehingga mendapat sorotan dari baginda Rasulullah. Maka menurut kelompok yang kedua Hadîts ini merupakan suatu koreksi terhadap bangsa Persia yang telah keliru dalam memposisikan sosok wanita, dan bukan pelarangan terhadap kepemimpinan puncak bagi wanita dalam suatu negara.

Bertolak dari itu menurut kelompok yang kedua ini, tidak ada masalah bagi sosok wanita yang sudah memenuhi kreteria dan sudah mempunyai kelayakan, untuk menjabat sebagai seorang presiden dimana saja dan kapan saja. Di samping itu pula dalam konteks Indonesia bahwa presiden di negeri ini sebenarnya bukanlah pemimpin puncak, karena di atasnya masih ada kepemimpinan yang lebih tinggi sebagai pejabat tertinggi negara yaitu MPR ${ }^{15}$.

b. Pembagian Harta

Dalam pembagian harta warisan di Indonesia sudah berlaku satu sistem pembagian harta warisan (tirkat) yang disebut sistem gana-gini yang dianggap sebagai pengembangan dari sistem farâidh yang digariskan dengan berdasarkan nash (al-Qur'ân dan al-Hadîts). Pola pembagian harta warisan dengan sistem gana-gini ini sudah diterapkan dan bahkan sudah menjadi tradisi pada sebagian kawasan di Indonesia. Dan penerapan sistem ini merupakan satu bentuk ijtihâd dari sebagian tokoh masyarakat (kyai) di Indonesia yang terpaksa dilakukan karena munculnya rasa ketidak puasan dari sebagian masyarakat awam terhadap sistem farâidh yang ada.

Fenomena ini termasuk bagian dari penerapan sistem yang sudah mengarah kepada pandangan yang kontekstual, yakni penerapan

15 Pernyatan KH. Hasyim Muzadi dalam sebuah acara Temu Kandidat CapresCawapres pada stasiun Lativi tanggal 20 Juni 2004 


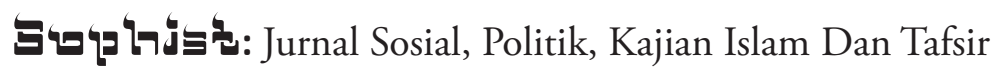

terhadap teks keagamaan dengan mempertimbangkan sosio kultural masyarakat yang ada, di mana suami dan isteri sama-sama bekerja, misalnya sama-sama pegawai negeri, pedagang, atau petani, bahkan kadang-kadang yang bekerja lebih berat justru sang isteri, berbeda sama sekali dengan sosio kultural masyarakat Arab pada masa lima belas abad silam di mana peran sang isteri pada masa itu pada umumnya hanya sebatas sebagai ibu rumah tangga saja. 
Vol. 1, No. 2, Desember 2018

\section{Daftar Pustaka}

Al-Bukhâri, Shahîh al-Bukhârî, Juz 2 (Kairo: Mathba'ah Salafîyah, 1990)

Harun Nasution, Islam Rasional, (Bandung: Mizan, 1995)

http://data.jakarta.go.id/dataset/data-lurah-di-lingkunganpemerintah-provinsi-dki-jakarta,,,,,, diakses pada tanggal 07 November 2017 Pukul 14.50 WIB

Lorens Bagus, Kamus Filsafat (Jakarta: PT. Gramedia Pustaka Utama, 2002)

Quraisy Syihab, Membumikan al-Qur 'an (Bandung: Mizan, 1998)

Sjechul Hadi Permono, Dinamisasi Hukum Islam dalam Menjawab Tantangan Era Globalisasi (Kudus: Pustaka Firdaus, 1998)

Sjechul Hadi Permono, Pembaruan Hukum Islam di Indonesia, Makalah disampaikan pada Konferensi Nasional Kajian Islam di Indonesia Tahun 2004 di Banda Aceh 